TAPROBANICA, ISSN 1800-427X. January, 2015. Vol. 07, No. 01: pp. 40-42.

(C) Research Center for Climate Change, University of Indonesia, Depok, Indonesia \& Taprobanica Private Limited, Homagama, Sri Lanka www.taprobanica.org

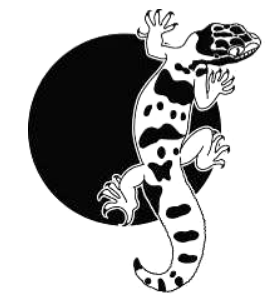

\section{On two rare cerambycid beetles (Coleoptera) from India}

Two unique cerambycid beetle species, which were collected from Kerala in 1997, were recently identified as Anoeme andrewesi Gahan, 1906 (Prioninae, Meroscelisini) and Zoodes maculatus (White, 1855), (Cerambycinae, Hesperophanini). Of the two species, $Z$. maculatus was previously only known from Sri Lanka; therefore, this is a new locality record and addition to the Indian faunal list of Cerambycidae. Types of both species are preserved in the Natural History Museum, London, UK (BMNH). Brief descriptions and color photographs of these two species are presented here. Both specimens were collected approximately $6 \mathrm{~km}$ North of Munnar, Kerala, India, on 14 April 1997, by a local collector. These are now preserved in E. Vives's private collection, Barcelona, Spain.

\section{Anoeme andrewesi Gahan, 1906 (Fig.1A)}

Specimen examined: Male, (No. 0184) length $15 \mathrm{~mm}$, breadth $4 \mathrm{~mm}$.

Redescription: Elongate beetle with reddish testaceous body, with head and prothorax slightly darker. Head with vertex somewhat rugose punctate, front sparsely punctate; mandibles prominent and inclined; eyes large, deeply emarginate, coarsely facetted with upper lobes very close to each other; antennae long, thin except for scape, setose, in male at least half of $8^{\text {th }}$ and $9^{\text {th }}$ to $11^{\text {th }}$ antennomeres passing beyond the elytral tip. Prothorax slightly shorter than head, finely punctured, partly setose, rounded at the sides with a feeble tubercle like projection, a wide sinuate grove behind anterior margin where the prothorax is distinctly narrowed and a narrow sulcus at the posterior margin. Elytra wider than prothorax at the base, very narrow and elongate, more than three times as long as broad at the humerus, coarsely and confusedly punctured all over, sparsely pilose, with two distinct costae that travel along the middle of the disc, somewhat obliquely, but stop short without reaching the apex; elytral tip somewhat truncate with a small spine at the suture. Legs relatively short, slender, metafemur much shorter than abdomen, metatibia somewhat broad in the middle and with a fine dorsal carina. Ventrally procoxae very prominent and close to each other, with a very narrow prosternal process in between.

Anoeme andrewesi was described from Nilgiri Hills in S. India, but has probably not been collected since original description. A checklist of the Cerambycidae from Tamil Nadu, S. India, published by ZSI (Namboodiri \& Thirumalai, 2009), includes this species but it is not clear if a fresh specimen was collected in Nilgiri Hills, as no collection details or images are provided in that list. Majumder et al. (2014) listed Prioninae from Central India, based on Norbert Delhaye's list of Indian Prioninae on the internet (www.prioninae.org), and included $A$. andrewesi but again no fresh collection records or image were provided.

Zoodes maculatus (White, 1855) (Fig. 1B)

Falsoplatocera theresae Pic, 1947 syn. nov.

Specimens examined: Female, (No. 1212), length $21 \mathrm{~mm}$, breadth $6 \mathrm{~mm}$. Female, MNHN uncat. (holotype of Falsoplatocera theresae Pic, 1947), length $\sim 20 \mathrm{~mm}$, collected by Pic.

Redescription: Beetle with tegument dull reddish or testaceous, with elytra slightly lighter, elongate with elytra about two and half times as long as breadth at the humerus, with fine pubescence all over the body and a pattern of maculae on prothorax and elytra. Head squarish as seen from above; eyes large, deeply emarginate with a larger lower lobe; antenniferous tubercles prominent and with a ridge between the two; antennae longer than body, pilose, scape short, just reaching the 
posterior margin of the head, dilated at the tip. The vertex finely punctate, the area between antennae, and on front, covered with long hairs; mandibles sclerotized, black in the distal half and with a sharp tip. Prothorax transverse, anterior margin slightly arched and narrowly black, posterior margin sinuate and also black, rounded at the side with a minute tubercle, with two prominent black tubercles placed transversely in front of the middle of the disc. Elytra moderately elongate, broader than prothorax at base, with two indistinct discal costae in anterior two-third, laterally shallowly sinuate in anterior one third, then slightly broad behind the middle, distal one-third imperceptibly narrowing, apex rounded on the outside but truncate towards the suture and with a small spine at sutural angle (which is not visible due to long pubescence). Scutellum small, blackish. Pattern of black maculae on elytra as follows: a faint rounded macula on the middle of the disc, slightly beyond the scutellum, two elongate blackish marks just in front of the middle (premedian) on the disc and another pair of broad, elongate, oblique bands behind the middle on the disc (post-median) forming ' $V$ ' like shape. A thin blackish line joins the outer band of these pre- and post-median black bands; the outer elytral border also narrowly black. Legs slender, moderately long, metafemur not extending beyond the tip of abdomen.

Zoodes maculatus was originally described from Ceylon (now Sri Lanka) and has not been so far added to the Indian faunal checklist. Here we are providing the first authentic record of this species from India. This seems to be a rare species because, although included in the recent checklist of Sri Lankan Cerambycidae (Makihara et al. 2008), the authors did not get to see any specimen. Lacordaire (1868) also gave the habitat of the species as "Hab. Ins. Taprobanâ". Pu (1981) mentioned this species from China (Yunnan) and Hua (2002) reported it from the Island of Hainan, probably by confusion with Zoodes fulguratus Gahan, 1906, which is common in China. There is another closely related species, described by Gahan (1906) as Zoodes quadridentatus, which is distinguished from $Z$. maculatus, (in words of Gahan) by "the apex of each elytron distinctly truncate and bidentate, the tooth at the outer angle as strong as that at the suture". We have also studied the Holotype of Falsoplatocera theresae (MNHN Paris) and the specimen described by Pic (1947) matches perfectly with Zoodes maculatus (White) hence we are treating $F$. theresae as a junior objective synonym of $Z$. maculatus (White).

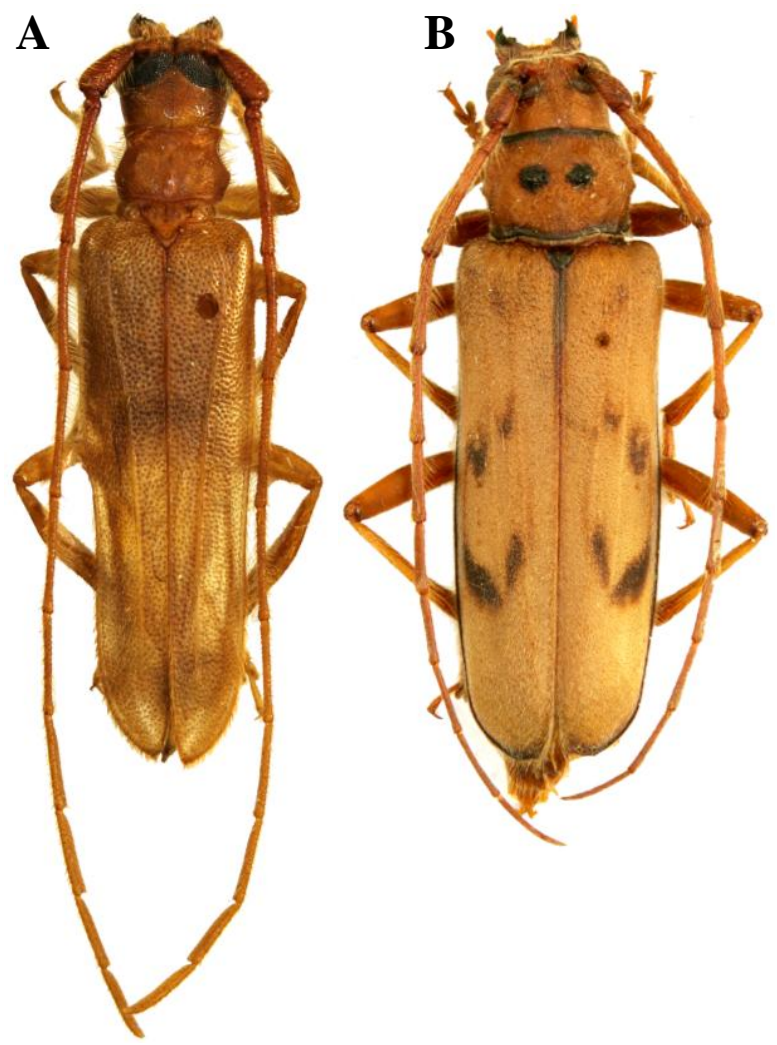

Figure 1: (A) male Anoeme andrewesi, (B) female Zoodes maculates.

\section{Literature cited}

Gahan, C.J., 1906. The Fauna of British India including Ceylon and Burma. Coleoptera, Volume 1, Cerambycidae. Taylor and Francis, London: 329.

Hua, L.Z., 2002. List of Chinese Insects Zhongshan (Sun Yat-sen). University Press, Guangzhou. List of Chinese Insects 2: 1-612.

Lacordaire, J.T., 1868. Histoire Naturelle des Insectes. Genera des Coléoptères ou exposé méthodique et critique de tous les genres proposés jusqu'ici dans cet ordre d'insectes. Paris. Librairie Encyclopédique de Roret, 8: 552.

Makihara, H, A. Mannakkara ,T. Fujimura and A. Ohtake, 2008. Checklist of longicorn Coleoptera of Sri Lanka (1) Vesperidae and Cerambycidae excluding Lamiinae. Bulletin of FFPRI, 7 (No.407): 95-110.

Majumder, A., A. Raha, B. Mitra and Kailash Chandra, 2014. Contributions to the studies on 
Prioninae (Coleoptera: Cerambycidae) of central India with checklist of Indian species. Munis Entomology \& Zoology, 9: 848-857.

Pic, M., 1947. Falsoplatocera theresae Coléoptères du globe (suite). L'Échange, Revue Linnéenne, 63 (508): 5-8.

$\mathrm{Pu}$ F., 1981. New records of chinese longicorn beetles from Guangdong and Yunan. Acta Zootaxonomica Sinica, 6: 396.

Namboodiri, M.P.S. and G. Thirumalai, 2009, Insecta: Coleoptera: Cerambycidae. In Fauna of Tamil Nadu State, Zoological Survey of India, Kolkata: 91-97.

White, A., 1853. Catalogue of Coleopterous Insects in the Collection of British Museum. Part VII, Longicornia I, Taylor and Francis, London: $174+4$ pls.

\section{Acknowledgements}

We thank our respective institutions for facilities and encouragement, and especially to Th. Deuve and A. Taghavian of MNHN for facilities provided to study Cerambycidae types.

Submitted: 20 Sept. 2014, Accepted: 01 Dec. 2014 Section Editor: Alain Drumont

E. Vives ${ }^{1} \&$ H. V. Ghate ${ }^{2}$

${ }^{1}$ Museu de Zoologia de Barcelona, P.O. Box 593,

Barcelona 08003, Spain

${ }^{2}$ Modern College of Arts, Science and Commerce, Shivajinagar, Pune 411005, India E-mail: hemantghate@gmail.com 